\title{
Coastal karren features in temperate microtidal settings: spatial organization and temporal evolution
}

\author{
Lluís GÓMEZ-PUJOL ${ }^{1,2} \&$ Joan J. FORNÓS2* \\ ${ }^{1}$ Mediterranean Institute for Advanced Studies, IMEDEA (CSIC-UIB), Miquel Marquès 21, 07190 Esporles \\ (Balearic Islands, Spain) \\ ${ }^{2}$ Departament de Ciències de la Terra, Universitat de les Illes Balears, Cra. Valldemossa km 7.5, 07122 Palma de Mallorca \\ (Balearic Islands, Spain)
}

Received February 2010; accepted April 2010

Available online 27 April 2010

DOI: $10.5038 / 1937-8602.55 .1 .5$

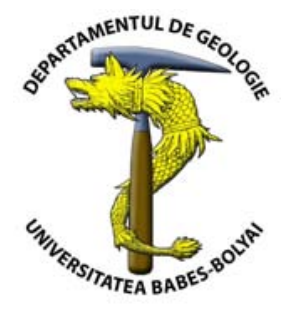

\begin{abstract}
Basin pools are the diagnostic feature of coastal karren landscape in temperate settings. According to size and connectivity parameters four morphological zones are identified along limestone coastal profiles. Each zone reflects the balance between the effects of physical and chemical weathering-erosion agents. Broadly, marine abrasion, bioerosion, and biologically driven solution show a larger influence seaward, whereas non-biologically driven solution enhances its participation landward.
\end{abstract}

Key words: coastal karren, basin pools, biokarst, Balearic Islands, Spain.

\section{INTRODUCTION}

Limestone seacoasts display at least three main distinctive features: notches, pinnacles and a high density of small-scale circular forms (i.e., etched surfaces and pans). The latter ones, designed as coastal karren, are understood as an assemblage of small (down to millimetres) to largescale (up to several metres) mainly dissolution features developed on carbonate coasts (Ford and Williams, 2007). These features and their development are strongly influenced by freshwater-saltwater mixing solution, sealevel change, wave action, wetting and drying, salt weathering and also by high primary porosity and lithologic heterogeneity of limestones (Taboroši et al., 2004). In addition to physio-chemical dissolution, there can also be bioerosion, bioconstruction and/or bioprotection (Naylor et al., 2002). According to the effectiveness of these different processes and factors (i.e. lithology and fracture control, tides or wave energy) a large spectrum of eroding carbonate coasts can be identified among two end members: the first dominated by mechanical erosion, and the second by weathering.

Coastal karren is a topic with a large but not with an abundant tradition in geomorphologic literature. Since Wentworth (1939), one of the earliest workers concerned with coastal karren features, the approach to the study of this topic has changed significantly. Earlier workers focused their efforts on morphological descriptions and spatial zonations across coastal profiles (Emery, 1946; Corbel, 1952; Guilcher, 1953; Dalongeville, 1977; Mazzanti and Parea, 1979), whereas modern researchers put their efforts into trying to identify and understand which processes and *Correspondence: Joan J. Fornós (joan.fornos@uib.es) agents operate on carbonate coasts (Folk et al., 1973; Schneider, 1976; Trudgill, 1976, 1987; Viles et al., 2000; Lundberg and Lauritzen, 2002; Moses 2003).

Following in the latter tradition, the aim of this paper is to explore and characterize assemblages, organization and processes involved in coastal karren development in a temperate microtidal environment such as the Balearic Islands (Western Mediterranean).

\section{STUDY SITES}

Mallorca and Menorca are the two largest islands of the Balearic archipelago, which is located at the centre of the Western Mediterranean (Fig. 1). They have a typical Mediterranean climate with hot dry summers and mild wet winters. The mean annual temperature is approximately $17^{\circ} \mathrm{C}$, with mean winter and summer values of 10 and $25^{\circ} \mathrm{C}$ respectively; the mean annual precipitation is about $500 \mathrm{~mm}$ and is mostly concentrated in autumn (Guijarro, 1986). The Western Mediterranean presents a temperate, oligotrophic, clear sea environment. Waves rarely exceed $8 \mathrm{~m}$ in height and $50 \mathrm{~m}$ in wavelength; these values are considerably reduced nearshore where a maximum height of $4 \mathrm{~m}$ is achieved only during 6-8 Beaufort scale gales (Butzer, 1962). Forcing by tides is almost negligible in the Mediterranean with a spring tidal range of less than $0.25 \mathrm{~m}$, although changes in atmospheric pressure and wind stress can account for a considerable portion of sea level fluctuations.

Cliffed coasts are characteristic of a large part of the Mallorcan and Menorcan littoral zone. They are almost 
exclusively associated with deeper water offshore, and the $20 \mathrm{~m}$ isobath is generally found at distances considerably less than $500 \mathrm{~m}$ from the shoreline. Cliff morphology is closely related to the main characteristics of the large-scale morphostructural units of each island. Thus the general picture is one of plunging and composite cliffs that affect
Paleozoic to Upper Miocene rock outcrops. Cliff faces vary locally from 3 to $30 \mathrm{~m}$ in height and extend from 5 to $10 \mathrm{~m}$ below sea level. In these outcrops shore platforms and rocky coasts sculptured by coastal karren appear patchily and are closely related to lithology and structure control (GómezPujol, 2006).

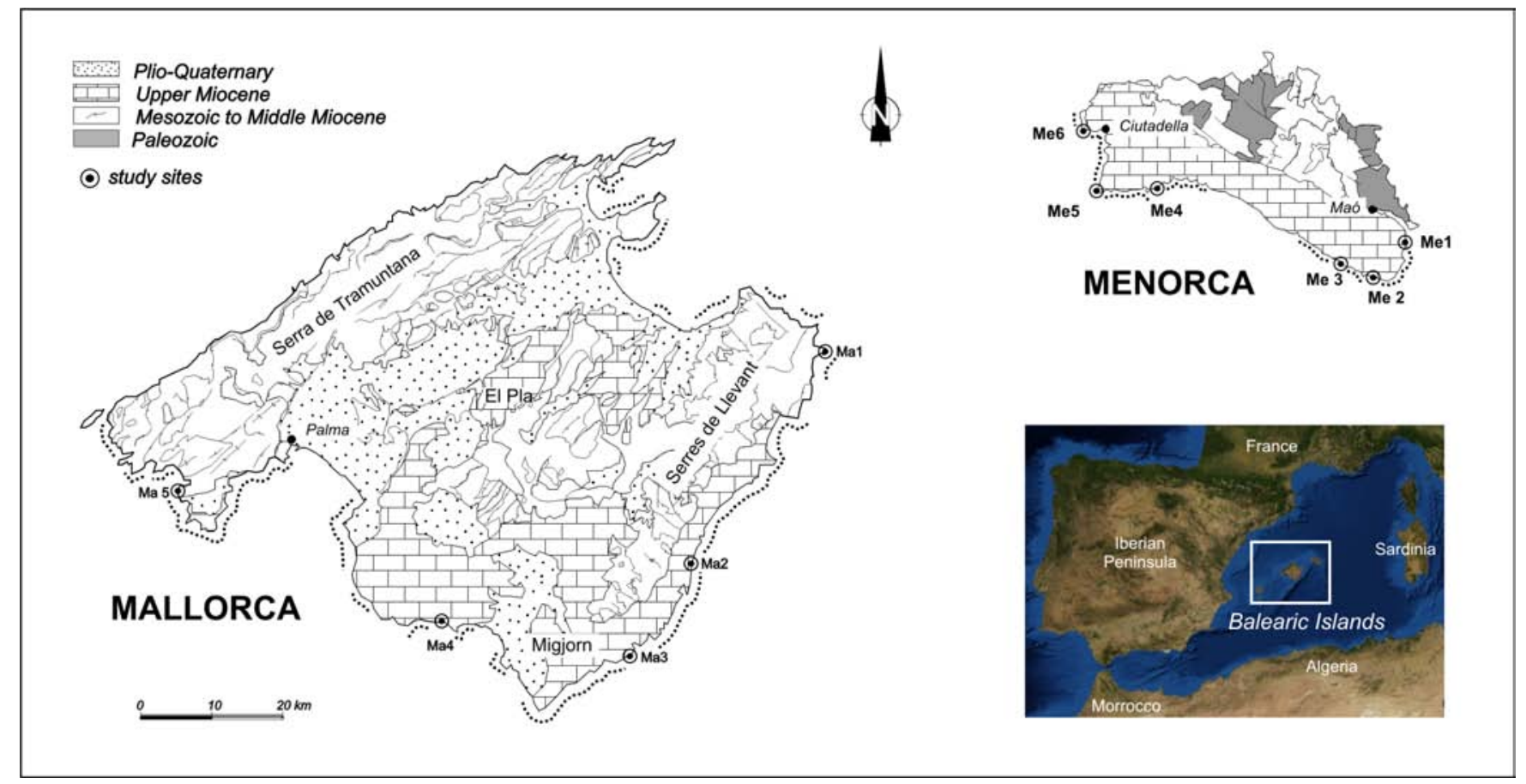

Fig. 1. Location inset and geological map of the Balearic Islands. Dotted line indicates coastline with conspicuous coastal karren features (Ma and Me refers to sampling sites).

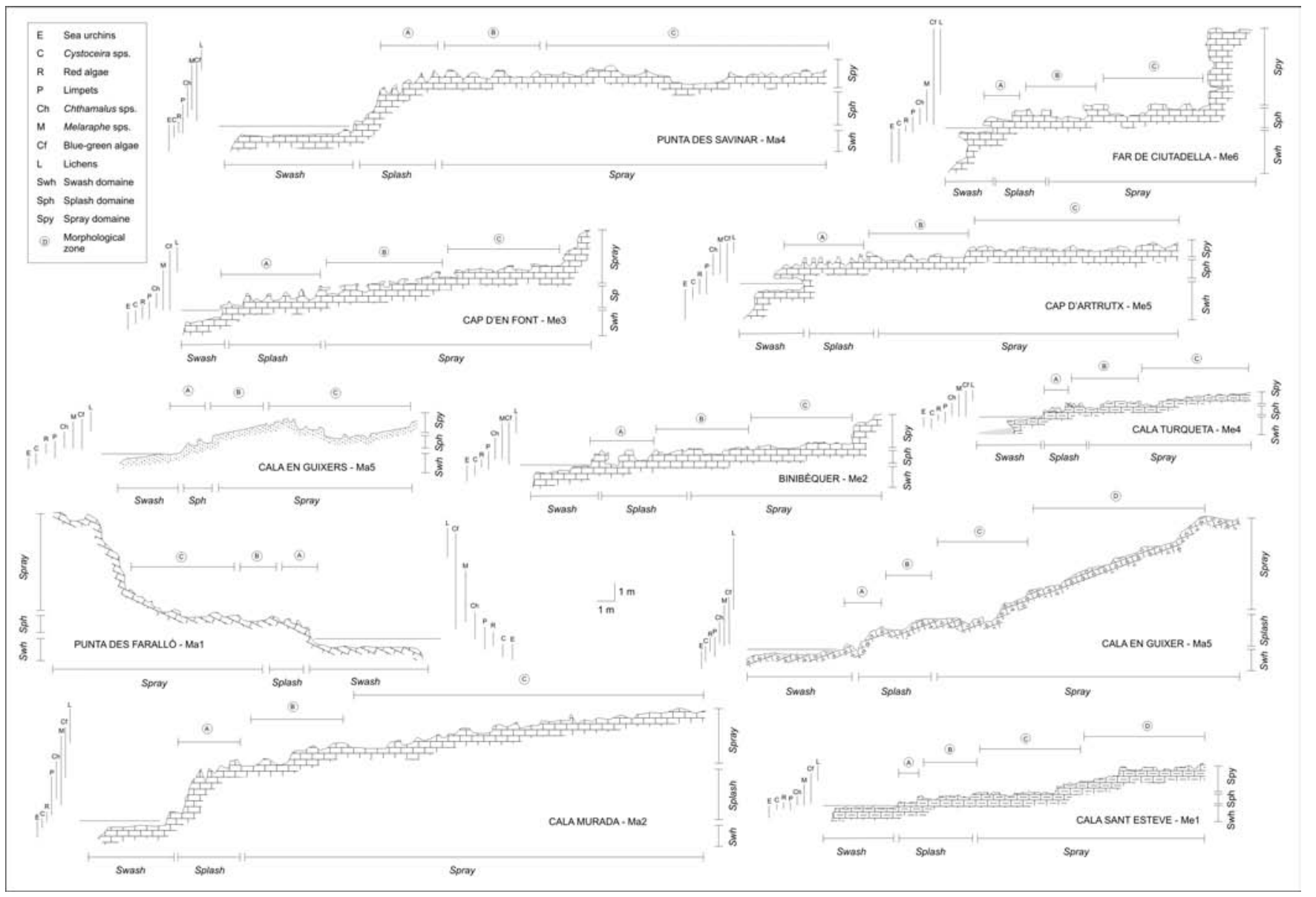

Fig. 2. Selected coastal karren profiles showing main morphological features, hydrodynamic gradient, and biological zonation. See locations in Fig. 1.

Studia UBB, Geologia, 2010, 55 (1), $37-44$ 


\section{MATERIALS AND METHODS}

The coastal karren was surveyed from the low water mark at the shore platforms up to the terrestrial transition zone using a tachometer TOPCOM ${ }^{\circledR}$ CTS210. On each profile the extent of hydrodynamic and biological zonation (Fig. 2) was marked according to coloration and key-species presence (Torunski, 1979; Schneider, 1976). The surveys documented the size and shape of karren features as well as comments focusing on any biological action. The morphometrical approach designed by Johansson et al. (2001) has been developed just for basin pools. It consists of taking the major morphometrical parameters -length, width, and depth- and classifying the shape according to a set of shape types; of assessing the connectivity degree between different basin pools; and of evaluating the number of joints that control the geometry of each karren feature.

\section{FORM ASSEMBLAGES}

Coastal karren features of the Balearic Islands can be grouped into three broad categories based on form properties and genetic factors: circular plan forms, linear plan forms -hydrodynamically or fracture controlled- and positive remnant forms (Gómez-Pujol and Fornós, 2010).

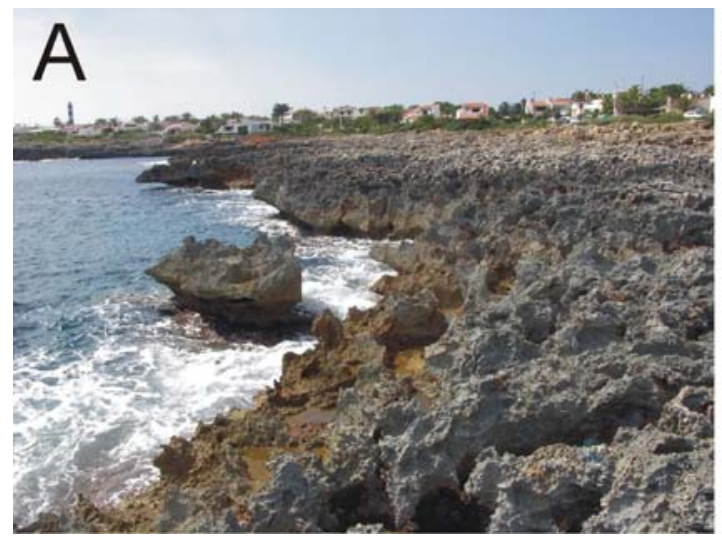

Other forms related to different processes involved in coastal karren (i.e., trottoir and blowholes) are also present. Table 1 shows the relative abundance of each type of form at different study sites according to the rock properties, profile slope and sea waves influence.

Of the many sites documented it can be concluded that basin pools are the diagnostic feature of coastal karren landscape near temperate settings. These depressions display an elliptical or irregular plan view and a flat or nearly flat bottom that is usually horizontal (Fig. 3). The walls are steep and may display a basal corrosion notch. Individual basin pools attain diameters of several meters and depths greater than one metre. Coalescence of adjoining pools is common, creating larger features with crenulated or irregular plans form. The origin of these features is largely attributed to dissolution (Ford and Williams, 1989), but biochemical processes are very important to their formation because they cause undersaturation of water in basins with respect to $\mathrm{CaCO}_{3}$ at night (Emery, 1946; Schneider, 1976; Trudgill, 1976) or directly as a result of biological corrosion and erosion of the substrate by cyanophytes (Dalongeville et al., 1994; Jones, 1989; Torunski, 1979) and snails, limpets or sea urchins which also attack rock mechanically (Hodgkin, 1970; Trudgill, 1987; Andrews and Williams, 2000).

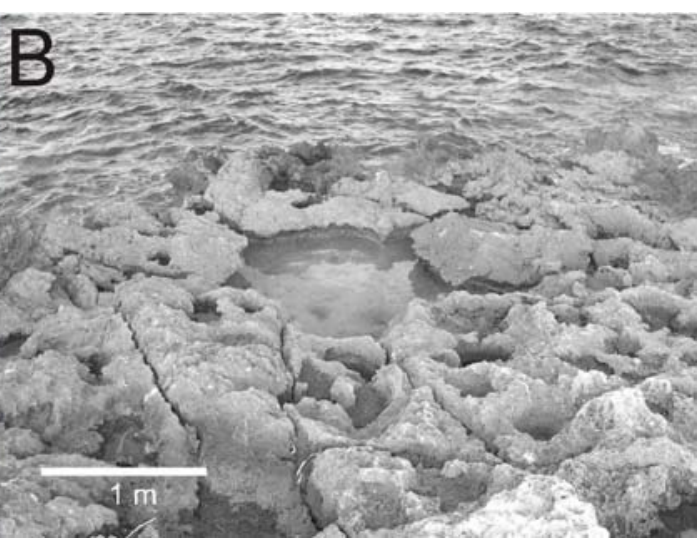

Fig. 3. Characteristic view of coastal karren (A) with conspicuous development of basin pools (B) (Ciutadella, Menorca).

Table 1. Summary of relative abundance of coastal karren features and associated forms in relation to the processes operating on the Balearic Island coasts (+++: very abundant; ++: abundant; +: present; $r$ : rare; -: absent).

\begin{tabular}{|c|c|c|c|c|c|c|}
\hline \multicolumn{2}{|c|}{ Morphological zonation } & Shore platform & Zone A & Zone B & Zone C & Zone D \\
\hline \multirow{7}{*}{$\begin{array}{l}\text { Circular plan } \\
\text { forms }\end{array}$} & Basin pools & $\mathrm{r}$ & + & +++ & +++ & + \\
\hline & Pits & + & +++ & ++ & & + \\
\hline & Micropits & - & +++ & +++ & ++ & + \\
\hline & Taffoni & - & - & - & - & + \\
\hline & Honeycomb & - & - & - & - & + \\
\hline & Rock pools & ++ & + & $\mathrm{r}$ & $\mathrm{r}$ & $\mathrm{r}$ \\
\hline & Subsoil tubes & - & - & - & + & ++ \\
\hline \multirow{2}{*}{$\begin{array}{c}\text { Linear forms } \\
\text { fracture controlled }\end{array}$} & Microfissures & - & - & $\mathrm{r}$ & + & + \\
\hline & Splitkarren & + & + & + & ++ & + \\
\hline \multirow{3}{*}{$\begin{array}{c}\text { Linear forms } \\
\text { hydrodynamically } \\
\text { controlled }\end{array}$} & Microrills & - & - & - & + & ++ \\
\hline & Rillenkarren & - & - & $\mathrm{r}$ & $\mathrm{r}$ & $\mathrm{r}$ \\
\hline & Decantation flutes & - & - & $\mathrm{r}$ & $\mathrm{r}$ & - \\
\hline \multirow{4}{*}{ Polygenetic forms } & Pinnacles & - & +++ & + & - & - \\
\hline & Notch & + & - & - & - & - \\
\hline & Trottoir & +++ & + & - & - & - \\
\hline & Blowholes & + & + & $\mathrm{r}$ & - & - \\
\hline \multicolumn{2}{|c|}{ Hydrodynamic zones } & \multicolumn{2}{|c|}{ Waves } & $S p$ & & pray \\
\hline
\end{tabular}

In the Balearic Islands basin pools range in width from $1.0 \mathrm{~cm}$ to $4.0 \mathrm{~m}$ and in depth from $10 \mathrm{~cm}$ to $1.6 \mathrm{~m}$ (Fig. 4 ). Differences between morphometrical parameters can be identified across the coast profile. Thus basin pools nearest to the sea are narrower than those that are far away; for instance in southern Menorca Upper Miocene sandstone and 
mudstones, the mean diameter for basin pools nearest to the sea is $0.62 \mathrm{~m}$ and landward this parameter rises to the 1.66 $\mathrm{m}$. The same is true for Mallorcan Upper Miocene mudstones and sandstones and Quaternary carbonate eolianites where width increases from 0.7 to $4.0 \mathrm{~m}$ and from 0.4 to $1.2 \mathrm{~m}$, respectively. On Upper Triassic rocks (deformed mudstones, Fig. 4) there do not appear to be differences in basin pool width between sampled zones.
Basin pool depth, although all features are characteristically tapered, is quite variable. Depth values change from one basin to another according to changes in facies and lithology. Additionally, basin pools can be isolated (more likely close to the land) or coalesced (more likely close to the sea): close to the sea basin pools are connected in 60 to $90 \%$ of cases and far away from the sea basin pools are isolated in 70 to $90 \%$ of cases (Fig. 5).

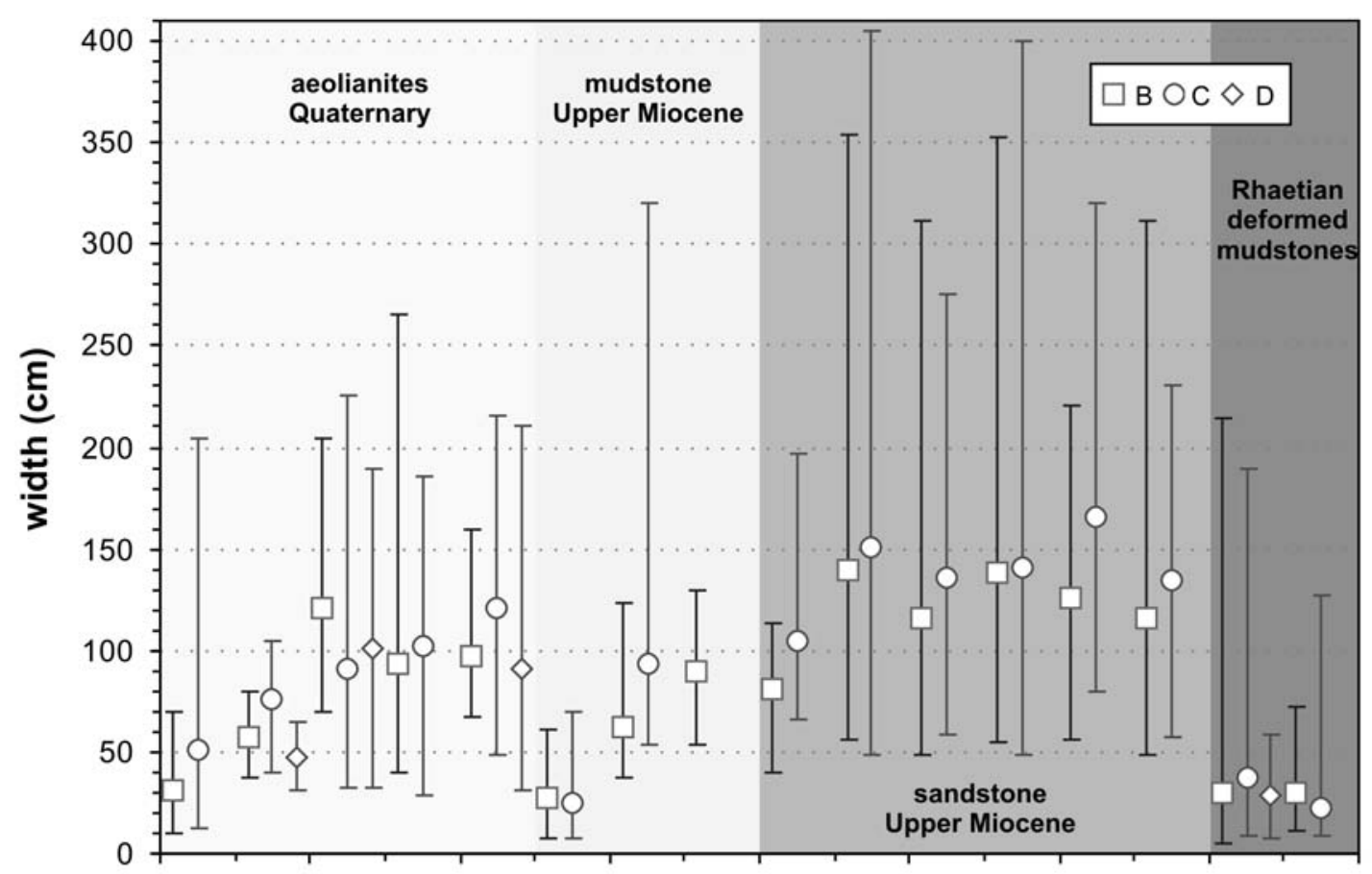

Ma5 Ma4 Ma3 Ma3 Ma2 Ma3b Me1 Me5 Me3 Ma3 Ma2 Me1 Me2 Me3 Ma5 Me1

Fig. 4. Basin pool width ranges according to the lithological substrate and the spatial zonation modules. ( $B, C$, and $D$ refer to the spatial zonation modules, see text).

Zone C

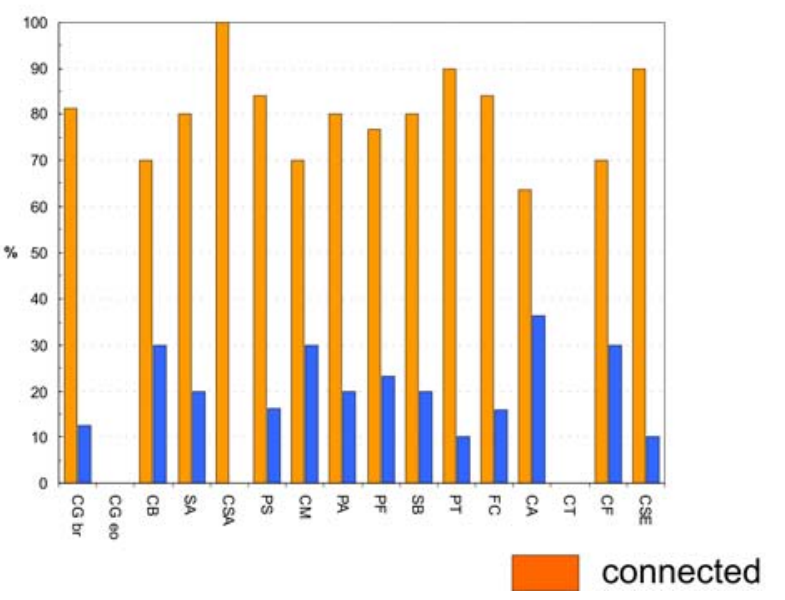

Zone D

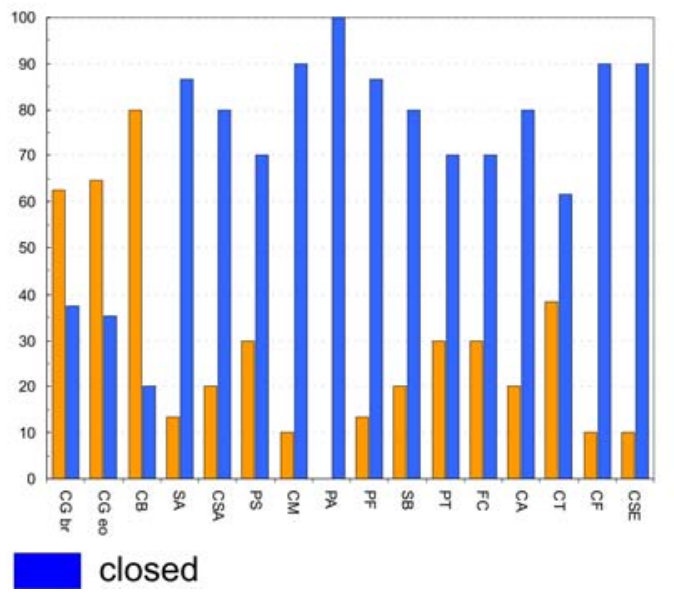

Fig. 5. Degree of connectivity between different basin pools along coastal karren zonation.

\section{SPATIAL ZONATION}

One of the most striking features of coastal karren in the Balearic Islands is that a general zonation based on four modules can be delineated. It is based on basin pools and other associated morphologies' relative abundance along the profiles, as well as on their shape attributes. The modules, are bounded seaward by a sub-horizontal shore platform 1 to $6 \mathrm{~m}$ wide, sculptured by sea-urchins and completely carpeted by green and brown algae. Sometimes it is preceded by a notch profile and landward, by the transition to fully terrestrial environments and maquis vegetation. According to Gómez-Pujol (2006) these modules are (Fig. 6):

Zone A: - This module is characterized by the transition from the swash to the splash hydrodynamic zone in quiet conditions. Waves completely reach this surface during storms. From a morphological point of view the presence of isolated pinnacles is the clearest feature, those near to the sea are sharper than those that are farther away. Their surface is completely fretted and the rock surface has a dark 
brown to blue-black coloration due to the intense colonization by cyanophytes and lichens (Rivularia sp., Pynerocollema $s p$.). Such pinnacles are understood to be the remnant of the basin pool evolution, being the only positive form described in the coastal karren assemblages (Moses, 2003; Gómez-Pujol and Fornós, 2010). In this module the biological component is dominated by a large number of individuals of Melaraphe neritoides or M. punctata; also limpets (mainly from Patella rustica and P. caerulea) are abundant at horizontal surfaces between pinnacles or vertical walls just above the scarp after the shore platform as well as snails as Monodonta turbinata and/or M. articulata. Joints widened by solution -splitkarren- that remain in zone A are colonized by filtering barnacles (Chthamalus depressus and C. stellatus), especially where waves and runoff water flow. The rock surface is very rough and abundant salt efflorescence occurs during dry episodes.

Zone B: - This block corresponds to the extension affected by wave splash. Pinnacles are the dominant feature although they are not isolated. Pinnacles are joined at their bases by a small chain -wall- resulting in a configuration of shallow basins flanked by triangular bodies of pinnacles. Densities of Melaraphe neritoides and M. punctata winkles increase in comparison to the previous module and the limpets and barnacles described above decrease.
Zone $C$ : Sea spray is the dominant hydrodynamic condition and rocks are subjected to splash only during storms. Basin pools have a greater degree of connectivity, between 60 to $90 \%$ of cases, and those nearest to the Zone B share walls between them. Many show overhanging sidewalls, usually fretted by micropits, where densities of Melaraphe neritoides are greatest $\left(200\right.$ to $600 \mathrm{ind} / \mathrm{m}^{2}$ in Miocene calcarenites and up to $1,700 \mathrm{ind} / \mathrm{m}^{2}$ in Quaternary carbonate eolianites) (Palmer et al., 2003; Kelletat, 1980). All basin pools have basal coverings of cyanophytes while some also contain a layer of salt crystals. The rock surface between basins presents a rough texture and much of it is colonized also by cyanophytes giving a characteristic blue to grey color to the rock.

Zone D: - In this block isolated basin pools (ca. 85\% of cases) are the key feature. The rock surface between them is smooth or rounded inland where lichens (mainly Verrucaria $s p$.) are present. Smooth rock surfaces are common on basin walls and floors. Winkles such as Melaraphe neritoides are abundant (271 to $897 \mathrm{ind} / \mathrm{m}^{2}$ ). Beyond the upper limit of Zone D, where microrelief is not conspicuous, forms such as microrills or subsoil tubules appear. These last features lie in the zone of lichens and halophytes, within the transition to the spray domain to the fully terrestrial environments.

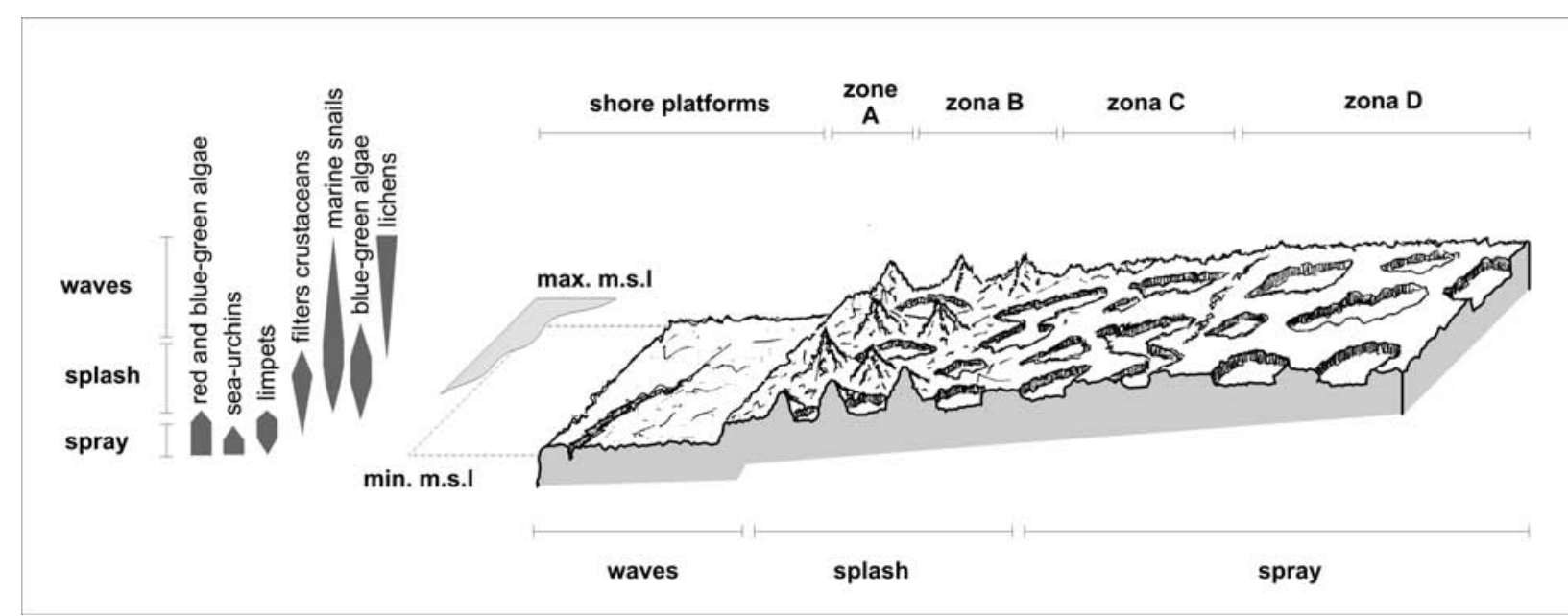

Fig. 6. Hydrodynamic, biological and morphological zonation model of coastal karren in the Balearic Islands.

At least four main weathering and/or erosion vectors can be drawn on coastal karren systems according to the organization of karren forms and the controls exerted by structure, geological history and the hydrodynamic gradient (Fig. 7). The first one corresponding to dissolution weathering is understood as inorganically-driven dissolution. This vector decreases seaward and has its main morphological expression in subsoil exhumed forms. It is especially important in zones $\mathrm{C}$ and $\mathrm{D}$. Biological weathering or biologically-driven dissolution is the second vector and is the most important weathering agent along coastal karren profiles. Because the biochemical action of organisms controls the chemical properties of water standing in basin pools, biological weathering affects most of the profile, although it is also very important and intensive in zones $\mathrm{A}$ and $\mathrm{B}$ and has a minor role in zone $\mathrm{C}$. The third vector, biological erosion, caused mainly by grazers limpets, sea urchins and snails, is constrained mainly to zone $\mathrm{A}$ and to the vertical walls of sea edge profiles. Finally, salt weathering affects mainly zone A and decreases landward according to the extent of the splash and spray domains.

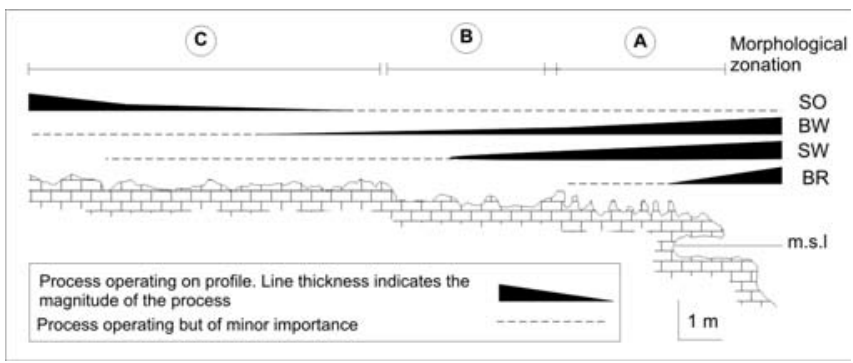

Fig. 7. Process-form zonation. (SO: Dissolution; BW: Biological weathering: SW: Salt weathering; BR: Bioerosion).

\section{TEMPORAL EVOLUTION}

A descriptive model for coastal karren development in temperate microtidal settings is addressed below. The very sheltered cliff represents the simplest stage of profile formation (T1 on Fig. 8), where the rock surface is not yet affected by marine agents and still suffers 
mainly terrestrial weathering processes. The initial development of basin pools by means of combined inorganically and biologically controlled solution draw the second stage of the model (T2 on Fig. 8). At this time stack basin pool development may be enhanced by rock joints and discontinuities.

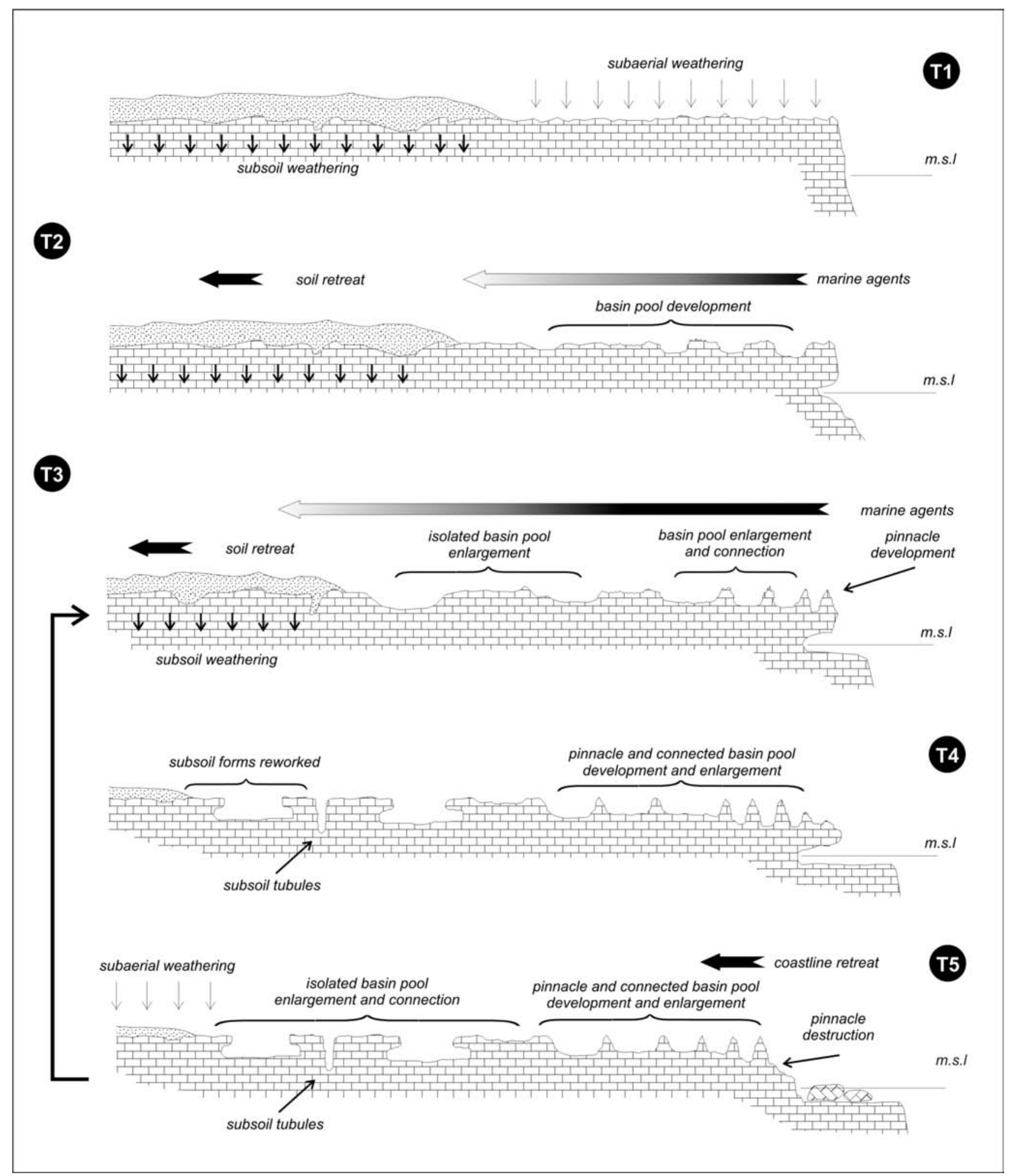

Fig. 8. General evolution model for coastal karren development in temperate microtidal settings. The shading on the arrows indicates the magnitude and importance of the process.

The next stage is characterized by the landward retreat of the soil, leaving a smooth rock surface to the action of water, by means of splash and spray inputs, and to the biological colonization. At the same time older basin pools become wider and deeper and some of them share their walls. Those basin pools, which are nearest to the sea edge, suffer the physical action of wave impact during storms and Studia UBB, Geologia, 2010, 55 (1), 37 - 44 their thinner walls break down. According to the density of joints and to the rock properties some points or basins pools walls may be more resistant and will remain as pyramidal bodies; this is the initial pinnacle development (T3 on Fig. 8). Rock surfaces nearest to the sea increase their roughness due to biological weathering and erosion combined with salt weathering. Previous basin pools developed in zone B have 
evolved to isolated pinnacles, and those previously isolated basins pools become wider and share the walls between them. Some of them coalescence and initial elliptical plan forms evolve to complex forms.

In more advanced temporal stages, the landward isolated basin pools enlarge. Soil retreat allows the interaction between marine forms and subsoil forms. Additionally, at the seaward edge, a narrow shore platform and a notch develop and former isolated pinnacles nearest to the sea edge are destroyed leaving some irregular topography on the notch roof (T4 on Fig. 8). The following stage corresponds to the notch-visor break and this fact implies the displacement of the coastal karren system landward at the same time that the shore platform enlargement occurs (T5 on Fig. 8). The model runs in a closed-cycle manner as the evolution of the coastal karren system follows from the third described stage.

\section{CONCLUSIONS}

Basin pools are the diagnostic feature of coastal karren landscapes in temperate settings. According to the size and connectivity parameters four morphological zones are identified along limestone coastal profiles. Each zone reflects the balance between the effects of physical and chemical weathering-erosion agents. Broadly, marine abrasion, bioerosion and biologically driven solution show a larger influence seaward, whereas non-biologically driven solution enhances its participation landward. A temporal evolution model of coastal karren assemblages is proposed integrating form and process zonation. Two features should be pointed out from this model:

The first is that pinnacles are not a morphological features by themselves because they are the remnants of the basin pool evolution; and secondly that there are different stages of basin pool evolution in the same profile.

Coastal karren systems are organized according to the biological zonation and the hydrodynamic gradient, developing the imprints of geologic history and structural control on profiles a secondary role. Thus, the coastal karren cannot be understood as classic exokarstic landforms although dissolution is the dominant process on those limestone rocks. Here, this is induced directly or indirectly by biological activity. In that sense, coastal karren fits properly in the biokarst framework proposed by Viles (1984).

Acknowledgements. The research reported here is a contribution to the project MICINN CGL2009-07392 (Spanish Government). LGP is indebted to the "Consejo Superior de Investigaciones Científicas" (CSIC) for the funding provided in the JAE-Doc Program.

\section{R E F E R E N C E S}

Andrews, C., Williams, R.B.G. 2000, Limpet erosion on chalk shore platforms in the southeast England. Earth Surface Processes and Landforms, 25: 1371-1381.

Butzer, K.W. 1962, Coastal geomorphology of Majorca. Annals of the Association of American Geographers, 52: 191-212.

Corbel, J. 1952, Les lapiaz marins. Revue Géographique de Lyon, 37: 379-380.
Dalongeville, M. 1977, Formes littorales de corrosion dans les roches carbonatees au Liban. Étude morphologique. Mediterranée, 3: 21-33.

Dalongeville, R., Le Campion, T. \& Fontaine, M.F. 1994, Bilan bioconstruction-biodestruction dans les roches carbonatées en mer Méditerranée: étude expérimentale et implications geomorphologiques. Zeitschrift für Geomorphologie, 38: 457-474.

Emery, K.O. 1946, Marine solution basins. Journal of Geology, 54: 209-228.

Folk, R.L., Roberts, H.H. \& Moore, C.H. 1973, Black phytokarst from Hell, Cayman Islands, British West Indies. Geological Society of America Bulletin, 84: 2351-2360.

Ford, D.C., Williams, P.W., 1989, Karst Geomorphology and Hydrology. Unwin Hyman. London, $601 \mathrm{p}$.

Ford, D.C., Williams, P.W., 2007, Karst Hydrology and Geomorphology. Wiley. London, 562 p.

Gómez-Pujol, L. 2006, Patrons, taxes i formes d'erosió a les costes rocoses carbonatades de Mallorca. Unpublished $\mathrm{PhD}$ thesis. Universitat de les Illes Balears, Palma, $237 \mathrm{p}$.

Gómez-Pujol, L., Fornós, J.J. 2009, Coastal karren in the Balearic Islands. In Karst rock features. Karren sculpturing (Ginés, A., Knez, M., Slabe, T. \& Dreybodt, W., Eds.), p. 483-502, Založba ZRC, Postojna.

Guijarro, A. 1986, Contribución a la bioclimatología de las Baleares. Unpublished Ph D Thesis. Universitat de les Illes Balears. Palma de Mallorca.

Guilcher, A. 1953, Essai sur la zonation et la distribution des formes littorales de dissolution du calcaire. Annales de Géographie, 331: 161-179.

Hodgkin, E.P. 1970, Geomorphology and biological erosion of limestone coasts in Malaysia. Geological Society of Malaysia Bulletin, 3: 27-51.

Johansson, M., Migon, P. \& Olvmo, M. 2001, Development of joint controlled rock basins in Bohus granite, SW Sweden. Geomorphology, 40: 145-161.

Jones, B. 1989, The role of microorganisms in phytokarst development on dolostone and limestones, Grand Cayman, British West Indies. Canadian Journal of Earth Sciences, 26: 2204-2213.

Kelletat, D. 1980, Formenschatz und prozessgefüge des "Biokarstes" and der küeste von Nordost-Mallorca (Cala Guya). Berliner Geographische Studien, 7: 99-113.

Lundberg, J., Lauritzen, S.E. 2002, The search for an artic coastal karren model in Norway and Spitzbergen. In Landscapes of transition (Hewittt et al., Eds.), p. 185203, Kluwer Academic Publishers.

Mazzanti, R., Parea, G.C. 1979, Erosione della "panchina" sui littorali di Livorno e di Rosignano. Bolletino Società Geologica Italiana, 96: 457-489.

Moses, C.A. 2003, Observations on coastal biokarst, Hells Gate, Lord Howe Island, Australia. Zeitschrift für Geomorphologie, 47: 83-100.

Naylor, L., Viles, H.A. \& Carter, N.E.A. 2002, Biogeomorphology revisited: looking towards the future. Geomorphology, 47: 3-14.

Palmer, M., Fornós, J.J., Balaguer, P., Gómez-Pujol, L., Pons, G.X. \& Villanueva, G. 2003, Spatial and seasonal variability of the macro-invertebrate community of a rocky coast in Mallorca (Balearic Islands): implications for bioerosion. Hydrobiologia, 501: 13-21. 
Schneider, J. 1976, Biological and inorganic factors in the destruction of limestones coasts. Contribution to Sedimentology, 6: 1-112.

Taboroši, D., Jenson, J.W. \& Mylroie, J.E. 2004, Karren features in island karst: Guam, Mariana Islands. Zeitschrift für Geomorphologie, 48: 369-389.

Torunski, H. 1979, Biological erosion and its significance for the morphogenesis of limestone coasts and for nearshore sedimentation (Northern Adriatic). Senckenbergiana maritima, 11: 193-265.

Trudgill, S.T. 1976, The marine erosion of limestones on Aldabra Atoll, Indian Ocean. Zeitschrift für Geomorphologie, 26: 164-200.
Trudgill, S.T. 1987, Bioerosion of intertidal limestone, Co. Clare, Eire - 3: zonation, process and form. Marine Geology, 74: 111-121.

Viles, H.A. 1984, Biokarst: review and prospect. Progress in Physical Geography, 8: 523-542.

Viles, H.A., Spencer, T., Teleki, K. \& Cox, C. 2000, Observation on 16 years of microfloral recolonization data from limestone surfaces, Aldabra Atoll, Indian Ocean: implications for biological weathering. Earth Surface Processes and Landforms, 25: 1355-1370.

Wentworth, C.K. 1939, Marine bench-forming processes II, solution benching. Journal of Geomorphology, 2: 3-25. 